\title{
THE PATTERN MAKING OF MEGA-SLUMS ON SEMANTICS IN SLUM URBAN CULTURES
}

\author{
Carmelo ZAPPULLA ${ }^{\mathrm{a}}$, Cristian SUAU ${ }^{\mathrm{b}}$, Alenka FIKFAK ${ }^{\mathrm{c}}$ \\ ${ }^{a}$ Department of Architecture (GIRAS, Research Group), Barcelona Architecture School, \\ Polytechnic University of Catalonia, Av. Diagonal, 649-651, 08028 Barcelona, Spain \\ ${ }^{b}$ Department of Architecture, Faculty of Engineering, University of Strathclyde, \\ 75 Montrose street, G11XJ, Glasgow, UK \\ ${ }^{c}$ Chair of Urbanism, Faculty of Architecture, University of Ljubljana, Zoisova 12, 1000 Ljubljana, Slovenia \\ E-mails: ${ }^{a}$ carmelo@externalreference.com; ${ }^{b}$ cristian.suau@strath.ac.uk; \\ calenka.fikfak@fa.uni-lj.si (correspondingauthor)
}

Received 06 October 2014; accepted 10 November 2014

\begin{abstract}
Mega-slums are dynamic laboratories for urban pattern making. Instead of surveying about stable urban symbols represented by formal orders and regular geometries, this study explores the semantic meaning of informal urbanism associated with chaos or randomness and often ignored by critique and conventions. Slums are forms of 'instant urbanity' that underscore alternative ways of self-organisation, which include bottom-up strategies, autonomous urban dynamics and spatial activation by remaking.

Are slum patterns representing a lack of symbolism or, on contrary, rich, complex, and fluid urban idioms? Urban informality without planning offers immense opportunities to investigate resilient urban forms and languages as complex systems throughout self-ruled structures. Slums are not only the result of urban economic asymmetries and social marginalisation but the elementary construction of survival urbanism, a randomised, agile and transformative pattern system.

Slum making is a form of subsistence urbanity that constructs transitory, elusive or spontaneous geometries. They differ in sizes, magnitudes and geometries regarding cultural, climatic and topographic conditions. Slums are unstable systems in continuous transformation. This essay questions the stigmatisation of informalised urban patterns as 'other' unclassified codes by analysing a selection of twenty mega-slums in the Americas, Africa and Asia regarding semantics, urban and geometrical meanings. Their urban tissues contain various symbols that activate the every-day production of spaces. They can be visible or invisible; passive or active; and formal or informal. A taxonomic tree of slums was developed to compare and map slum regions to describe similarities and differences among the selected case studies. From this analysis, a profound discourse appeared between informal settlements: tissue-patterns at macro level and cell-patterns in micro urbanisation. Does the macro pattern inform the micro, or vice versa?
\end{abstract}

Keywords: slums, pattern making, urban semantics, informality, instability, randomised systems, self-organisation.

\section{Introduction}

Symbols are normally associated with formalised cultural manifestations. A cultural symbol constitutes a tangible or intangible figure that is recognised by members that represent a common cultural identity. City making is a representation of cultural production. Its shape is distinct, reproducible and durable. It represents a cultural narrative that is embedded in the collective memory of dwellers. The urban morphology of many informal cities does not obey to any formal pattern making but to complex self-ruled spatial schemes. For instance, the symbolic meaning of a formal city is usually associated with order and the sense of a regular geometry whilst an informal city is normally correlated with chaos or mere randomness.

Nowadays more than 900 million people live in slums or informal settlements. This represents around one-third of the urban population in developing countries. By 2030 , it is expected that $85 \%$ of the world's pop- 
ulation will be in developing countries ${ }^{1}$. According to $\mathrm{UN}$, the number of mega-cities in the more developed regions will remain unchanged. However, new megaslums are emerging in the less developed regions ${ }^{2}$. There has also been a dramatic increase in the number of dwellers living in mega-cities (between 5 and 10 million inhabitants) in the less developed regions. There exist differences in the existing level and rate of informal urbanisations among the major areas of less developed regions of the world. The Latin American and Caribbean regions presently highly urbanised with $75 \%$ of its population. Asia and Africa reflect only half as much urbanisation with $37 \%$ and $38 \%$ of the population living in urban areas, respectively (Sharma 2003).

Slums rule! This urbanised planet Earth is mainly governed by 'invisible forces' of informal pattern making. Contradicting publics' perception, slums are not parts of formal urban tissues any longer but they are the dominant urban structure of mega-cities. Due to the rapid externalisation of production and services, the flows of capital and new transport networks, informal urban economies are transforming the urban pattern framework of slums and mega-slums towards dynamic systems of trade and migration. As result 'informalism' generates a type of 'instant urbanity' that constructs transitory, elusive or spontaneous geometrical patterns. They often underscore alternative ways in which every-day urban life is organised rather than disaggregated. What are the prevalent urban patterns in slums worldwide? In order to explore this question we have to select key precedents, and then group and classify them in terms of form, scale and geometry. In Table 1 we find that there are two types of prevalent patterns: randomised and also non-random.

Several taxonomic studies of patterns have been published mainly in terms of geometrical analogies, metaphors or pictorial comparisons. Nonetheless those studies have explored neither topological (cultural) nor topographic (mapping) in depth. This essay questions this stigmatization towards informalised urban patterns by analysing a variety of global mega-slums regarding their semantic, urban and geometrical values.

\section{The semantics of slum pattern making}

Symbols are commonly applied to formal iconographic representations. Urban symbolism is commonly associated with the enhancement of formal urban figures, landmarks and objects or pieces of collection exhibited like in world fairs. This cosmetic and curatorial approach towards urban symbolism is not a matter of study in this section.

Symbolism encompasses complex conceptual codes and pictorial representations of a worldview that operates in multiple levels and scales. They frequently take the form of images, words, sounds or gestures, and are used to express beliefs, thoughts and theories. Cities are the manifestation of symbolic worldviews and realities. Urban tissues contain various symbols (idea-icons) that activate the every-day production of spaces. They can be visible or invisible; passive or active; and formal or informal.

Nonetheless the classification of structural urban geometries has been the result of hitherto symbolic misconceptions and/or simplistic categorisations in which cultural topologies and geographic topographies are poorly analysed and embedded.

How can a new urban ontology of pattern symbols be built? Ontology deals with issues concerning what elements exist and how such elements can be grouped, related with a predominant trend and subdivided according to similarities and differences. Patterns are man-made symbols, mere templates. Pattern grading is an essential part of pattern or mold making. Grading a pattern is a way of sizing a pattern while maintaining the proportions of the original pattern.

Table 1. Prevalence of urban patterns in slums: categorisation according to form, scale and geometry

\begin{tabular}{ccccc}
\hline Prevalence & Form & Macro tissue & Micro cells & Pattern \\
\hline 1. Randomised & $\begin{array}{c}\text { Irregular/ } \\
\text { organic }\end{array}$ & $\begin{array}{c}\text { Cracking, branching \& } \\
\text { courtyard types }\end{array}$ & Unregulated infills \& dense units & Fractal-like \\
\hline 2. Non-random & Regular & $\begin{array}{c}\text { Rectangular, linear types, } \\
\text { courtyard types }\end{array}$ & $\begin{array}{c}\text { Regulated infills \& dense units } \\
\text { linear types }\end{array}$ & Grid \\
\hline
\end{tabular}

Source: authors.

\footnotetext{
1 Information taken from http://www.unhabitat.org and http://www.citiesalliance.org [accessed in 15 September 2014].

2 As a result, the population living in the mega-cities of less developed regions is expected to increase at an average annual rate of 3.6 per cent per year during 2000-2015, reaching 270 million persons by the end of the period. In contrast, the number of persons living in the four mega-cities of the more developed regions will hardly change, rising only from 67 million in 2000 to 71 million in 2015 (Source: United Nations Population Division 2002).
} 
The cartography of urban patterns map concepts with several cultural significances and semantic capacities to excite or objectify responses. Mapping ${ }^{3}$ is employed as the cartographic research technique and supported by geographic and urban maps, and satellite photography.

Unfortunately the current slum recovery strategies or even the eradication programmes do not consider the semantic capacities of informalised settlements. They reduce the richness and complexity of slum making structures by erasing its cultural meaning throughout generic slum removal, relocation, upgrading urban schemes and mono-functional public housing projects.

Slum making is a sort of self-ruled urbanism, an expression of informalism or survival urbanity from the South ${ }^{4}$. They represent a "new geography of centrality and marginality" (Brenner 2012) or differential spaces (Lefebvre 1974), which are characterised by motion, contestation, internal asymmetries, and discontinuous transgressions ${ }^{5}$ between territories in friction - formal vs. informal -, mainly in mega-cities. They play a crucial role in aligning the unplanned forces of global urbanisations by stimulating transgressive, agile and mutable urban forms.

Slums are an inter-urban (within the same city); trans-urban (between various cities) and trans-regional (between more regions, states or countries) occurrence. They are the outcomes of rapid rural-tourban migration (shanty towns), economic stagnation or abandonment (squatter areas), socio-political conflicts (refugee camps), or ecological dereliction (favelas). As result slums generate "instant pattern making" that constructs transitory, elusive or spontaneous geometries. They change frequently: seasonally, daily or even hourly. Slum pattern making obeys to regular and irregular predominant configurations. They differ in sizes, magnitudes and geometries regarding cultural, climatic and topographic dynamics.

\footnotetext{
3 Alfred Korzybski (1994) stated 'a map is not the territory it represents, but if correct, it has a similar structure to the territory, which accounts for its usefulness'.

4 Slums are mostly found in developing nations, but also in some parts of developed nations (Source: United Nations Human Settlements Programme [UN HABITAT] 2003).

5 Transgression (etymology): Late 14th century, from Old French transgression (12c.), from Late Latin transgressionem. In classical Latin, 'a going over', from transgressus, past participle of transgredi'go beyond', from trans- 'across' (see trans-) + gradi (past participle gressus) 'to walk, go'. Transgression (definition): 'An act that goes beyond generally accepted boundaries' (Source: Webster's Universal College Dictionary 1997).
}

\section{Methods: comparing structural features}

The term 'slum' has been investigated through various definitions and sources. The most common use derives from the United Nations: 'Slum' refers to urban inequalities in five important aspects: 'Slum' is of some use, since it highlights urban inequalities in five important aspects: access to safe water; access to sanitation; structural quality of housing; overcrowding; and insecure residential status (e.g. Prescott et al. 2013). As Jones (2011) states, even in apparently more progressive interventions, slums retain the negative connotation of a space of dirt, disease, toxicity and danger. Through a multiplicity of media, we are invited to be 'slummers', an endeavour in which we are expected to be either shocked by the scenes of misery, dirt and disease or to empathise with the slum dwellers fate (Jones 2011). From another viewpoint, Gilbert (2007) has argued that the word slum is "dangerous because it confuses the physical problem of poor housing with the characteristics of the people living there".

In the famous book Planet of Slums (Davis 2006) the center of the discussion commenced with the following question: "But what is a slum?" This fundamental query is also masked in various denominations: shantytown (Cite de Soleil), barriadas (San Juan), squatter settlements, favelas (Rocinha, in Rio de Janeiro), and backyard shacks (Mbare, Harare). As paradoxical fact slum is sometime advertised and exhibited as tourist attractions or extravaganza 'brandism'. Nonetheless, how does dwell someone whom lives in a micro-cosmos of marginalisation and informality?

This current research is based on observational fieldwork, and morphological analysis of slum-space making and its characteristics. In order to understand, describe, interpret and explain the problematique of 'slumness' in different geomorphological, social, economical, demographic and political situations, a critical reading allowed us to understand the changing of urban transformations. By combining sensorial urban features such as textures, colours, shading, noise, aromas along with infrastructural urban services such as lack of sanitation systems (sewerage or safe water supply) and drainage; water, soil and air managements; and natural or manned hazards at local scale we can experience a complex spatial layering: a 'place of indeterminacy'. Each place or loci represents a peculiar every-day urban scene almost intolerable to conventional life standards, with a relegated image of rich urban symbols and organisational patterns that obeys to specific subaltern cultures. 
If we compare the biological function in a 'slum' with a neurological system, we can observe the variability on two scales: (a) the apparent stability at macro level (SMS) and (b) the simultaneous dynamics of flows at micro level (FMS). The 'slum' constitutes the primary control center for the body. It consists of a genetic code made of demographics, location and topographies. The peripheral system consists of social networks streamed over the urban fabric that connects the rest of the structure to the SMS. The every-day urban life in both scales works together as scorecard information, whose main task is to record and re-create the immediate surroundings. The SMS processes all collected information. Its function is to establish synapsis and activate the rest of the body.

The processes of dynamic flows that take place between nucleation and dispersion shows a specific logic of non-planned development. However does this phenomenon occur also in planned or re-planning schemes? Does the tabula rasa decision making offer the best solution? The case of Kowloon Walled City (dismantled in 1992) can vividly illustrate this condition: "I spent five years photographing and becoming familiar with the Walled City, its residents, and how it was organized. So seemingly compromised and anarchic on its surface, it actually worked and to a large extent, worked well", said Mr. Girard on his website ${ }^{6}$ (Owen 2012). It will be reminisced as a phantasmagoric place of total beauty, a territory in motion ruled by various frictions and polarities, forms, geometries, cultural patterns, ethnicities and urban traditions. "Life must go on, house or no house, accommodation or no accommodation, and man must survive, government or no government" (Nigerian Tribune 15 August, 1992: 5; Kolawole Opeyemi et al. 2012).

The initial question of this study underpins how we interpret and process systemically this transgressive condition of slums into a 'readable' morphological urban map. In order to explore the 'readability' of the urban morphogenesis, efficiency and resilience of slum making we have compared and categorised representative slum-types from the mappamundi of Google Earth through the processes of urban informality, irregularity, self-organisation, transgressibility and complexity. The spatial versatility of the selected pattern structures reveals an unseen diagnosis that appraises the reductive and generic approaches of formal urban planning measurements. Do we need

\footnotetext{
${ }^{6}$ Greg Girard. Kowloon walled city: http://www.greggirard.com/ work/kowloon-walled-city--13 [accessed in 20 September 2014].
}

to layout urban design and planning only in terms of densities, floor space prescriptions, plot sizes or use permissibility parameters? What can be learnt from the semantics of patterns in slum urban cultures? If we already know that the life in slums is highly vibrant and unpredictable as are the statistics of demographical data (refer to Table 2, example: Ciudad Nezahualcóyotl (Table 2a)), density between 300 and 500 inhab./Ha (1983) or Orangi Town (Table 2c) with a population of approximately 2.5 million but officially $1,540,420$ (year 2010), then we should put emphasis on alternative factors associated with the culture and topography of 'pattern making' in order to explore the prospective condition of semantics in informal urbanisations.

The methodology employed for this study consists of literature review, mapping and taxonomic surveys of key precedents. It is focused on paradigmatic mega-slums, meticulously defined by this research team and then compared with other authors' outcomes from Sow (1983), e.g. Barros and Sobreira (2002), Davis (2006), Theodosis (2008), Olajide (2010), Gilbert (2011), Jones (2011), e.g. Kolawole Opeyemi et al. (2012), Raith (2013), e.g. Akinwale et al. (2013) and others. It involves the critical review of relevant archives (mapping and photography) related to paradigmatic precedents. This study articulates elements of geometrical, urban and landscape morphology with emphasis on informalised urban patterns. In doing so, it implements combined semantic and topological research methodologies as follows:

- Data collection of 31 worldwide slums in initial research phase. Cases were selected from different digital maps, processed in a table to obtain similarities, common features and general trends. All slum cases were organised according to area; demographics (population, density); urban history (origin, developing phases and key alterations); geomorphological (topography, reliefs, terrain type and climatic conditions) and urban morphological data (border conditions).

- Advanced selection of cases (from 31 to 15 case studies) and further five key insertions completing 20 case studies (refer to figures and urban populations in slums $s^{7}$ ). The selection criteria of all cases represent cultural, geographic and climatic regions evenly distributed.

7 Available from internet: http://commons.wikimedia.org/wiki/ File:Urban_population_living_in_slums.png\#mediaviewer/ File:Urban_population_living_in_slums.svg [accessed in 20 September 2014]. 
Table 2. Global slums (3 continents)
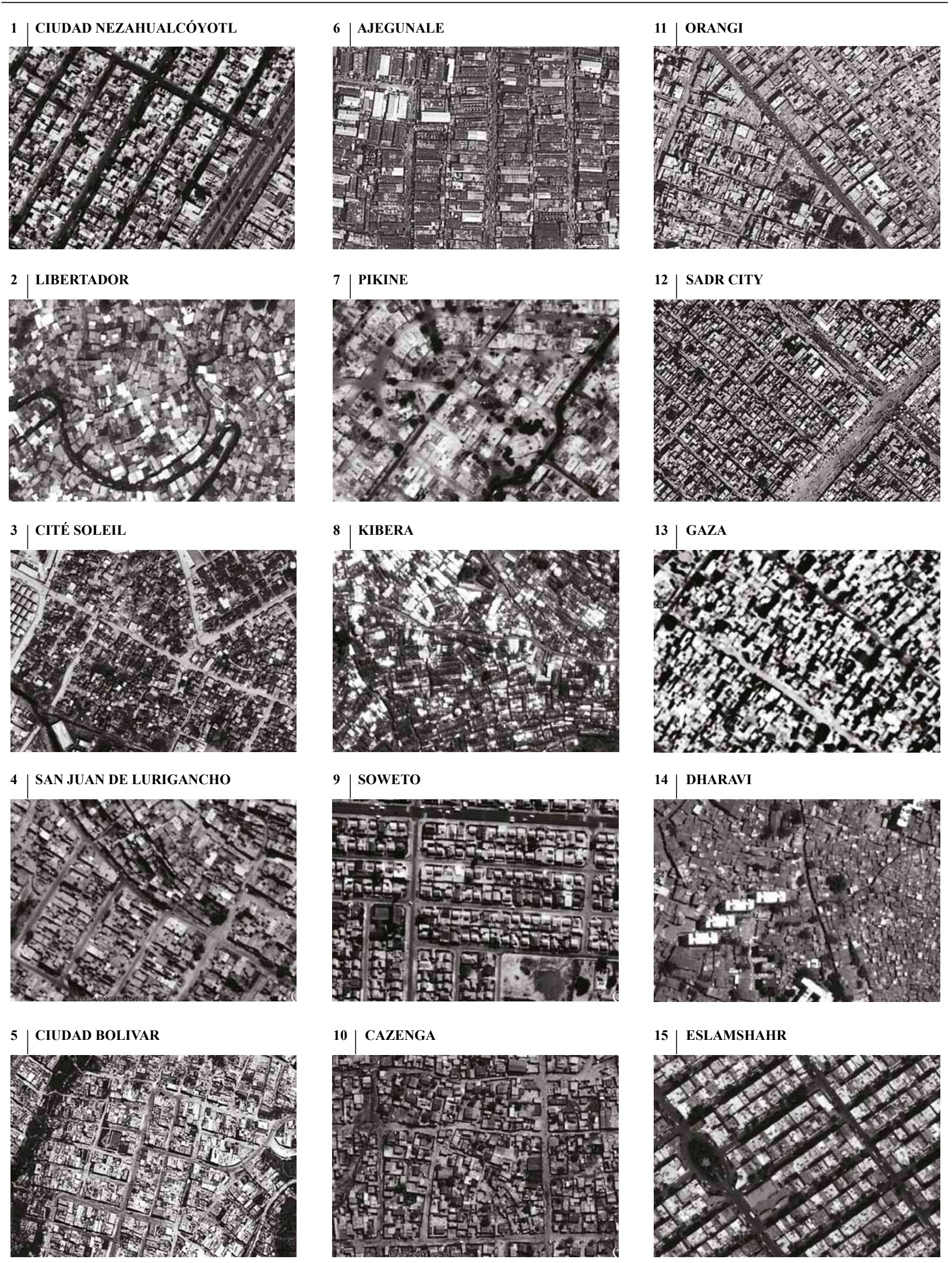

\section{CAZENGA}

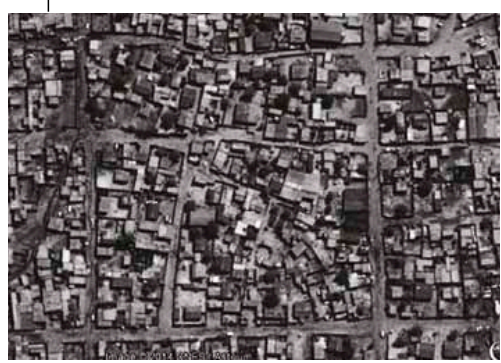

15 ESLAMSHAHR

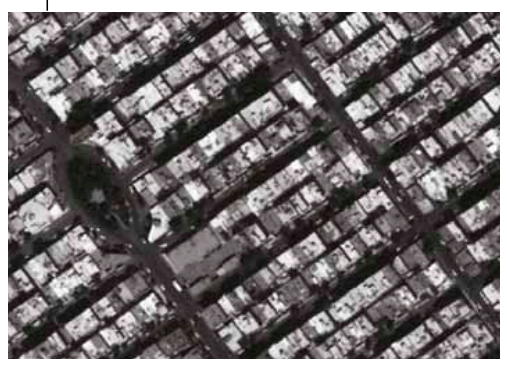


Table 2a. Slums in the Americas
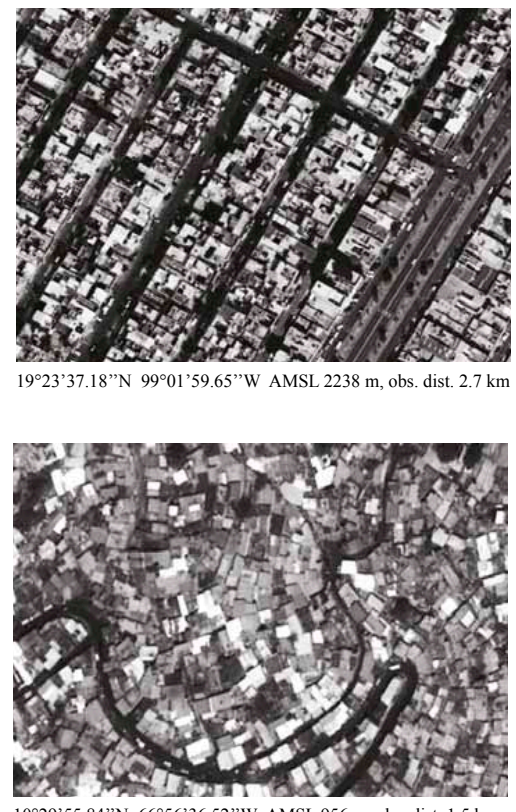

$10^{\circ} 29^{\prime} 55.84^{\prime \prime} \mathrm{N} 66^{\circ} 56^{\prime} 36.52 ” \mathrm{~W}$ AMSL $956 \mathrm{~m}$, obs. dist. $1.5 \mathrm{~km}$

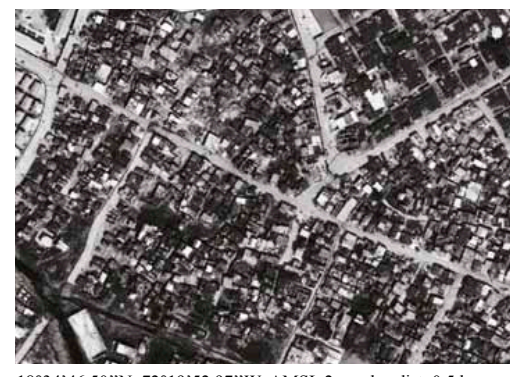

$18^{\circ} 34^{\prime} 46.50^{\prime \prime} \mathrm{N} 72^{\circ} 19^{\prime} 52.97^{\prime \prime} \mathrm{W}$ AMSL $2 \mathrm{~m}$, obs. dist. $0.5 \mathrm{~km}$

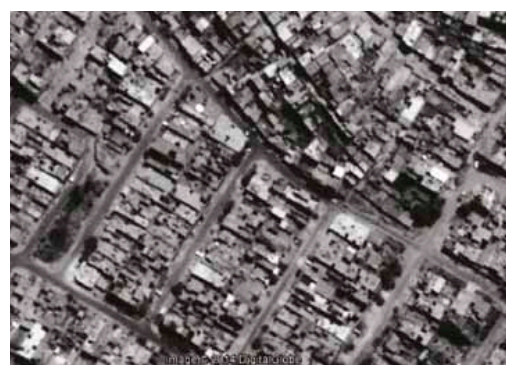

11 $57^{\prime} 48.01$ ”'S 76 $59^{\prime} 10.78^{\prime \prime}$ W AMSL $295 \mathrm{~m}$, obs. dist. $0.8 \mathrm{~km}$

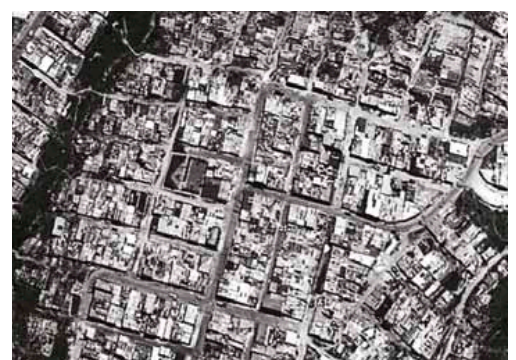

$4^{\circ} 32^{\prime} 16.60^{\prime \prime} \mathrm{N} 74^{\circ} 08^{\prime} 18.65^{\prime}$ W AMSL $2628 \mathrm{~m}$, obs. dist. $3.1 \mathrm{~km}$

$\begin{array}{cccc}0 & 50 & 100 & 200 \\ \text { Metric bar } & & \text { meters }\end{array}$

1 CIUDAD NEZAHUALCÓYOTL State of Mexico, Mexico

Common name: Ciudad Neza.

Foundation: Founded 1930s, Municipal Status 1963. Area: $25 \mathrm{~km}^{2}$.

Population: 1.2 million (year 2010).

Density: Between 300 and 500 inhab./ha (1983).

Characteristics: Mega blocks, informal markets.

Planned: The first settlement area was planned as a metropolitan integration area; Young settlement area - No plans foreseen. Morphology: Regular form which follows a rectangular macrogrid pattern. Formal sectors in shape of rectangles with party wall and inner informality. Dwellings: 1-3 storey(s), courtyards.

Referred to: http://elib.uni-stuttgart.de/opu volltexte/2008/3575/pdf/Kap_02.pdf

\section{$2 \mid$ LIBERTADOR \\ Caracas Metropolitan District, Venezuela}

Foundation: 1950 s.

Area: 3,446 ha.

Population: 1,002,780 inhabitants in barrios. Libertador of total barrio population is $73,54 \%$.

Density: 271 inhab./ha (1995).

Characteristics: Average slope is $40 \%$; number of floors 25 . Planned: Defined specific planning units for the purposes of upgrading and urban development; five major geographic areas. Morphology: Social housing; a devaluation of property values and urban decay. Urban fabric follows the topography in plan and elevation, extrusion of units is constant.

Referred to: https://eldorado tu-dortmund.de/

\section{CITÉ SOLEIL \\ Port-Au-Prince, Haiti}

Common name: Sun city.

Foundation: Founded in 1749 (Cap-Haïtien). Area: $22 \mathrm{~km}^{2}$.

Population: More than 250,000 (2013).

Density: 11,000 inhab./ $\mathrm{km}^{2}(2013)$.

Characteristics: A microcosm of all the hills in Haitian society:

endemic unemployment, illiteracy, non-existent public services.

Planned: After the earthquake in 2010, new ideas to create a comprehensive zoning plan (architect and planner Andres Duany).

Morphology: Cap-Haïtien was organised with gridiron street plan. After the earthquake, CS is a structure with 'small grain' shelters.

Referred to: http://www.relief20.com resilience/port-au-prince

\section{SAN JUAN DE LURIGANCHO Lima, Peru}

Foundation: Founded in 1960s. Area: $131.25 \mathrm{~km}^{2}$.

Population: 898,443 (2014)

Density: 6,845 inhab. $\mathrm{km}^{2}$.

Characteristics: Three types of progressive settlements: barria-

das asistidas, barriadas convencionales, pueblos jóvenes.

Planned: The responsibility for land regularisation in the shantytowns has moved to central government.

Morphology: Steep hillsides; many homes are inaccessible by road; urban layout and spaces vs. spontaneous settlements. Regular configuration, grids, freedom inside the blocks.

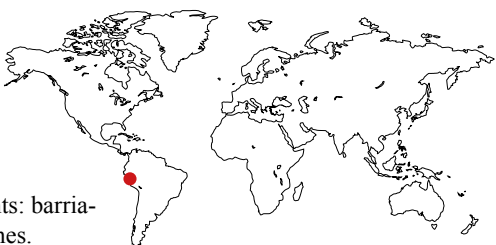

\section{CIUDAD BOLIVAR \\ Bogota, Colombia}

Original name: Santo Tomé de Guayana de Angostura del Orinoco Foundation: Founded in 1950s.

Area: $209.52 \mathrm{~km}^{2}$.

Population: 563,223 (2009).

Density: 1.633,63 inhab. $\mathrm{km}^{2}$.

Characteristics: Well-preserved historic center; a cathedral and

other original colonial buildings surround the Plaza Bolívar.

Planned: Association 'Provivenda' promoted squatting actions and self-housing projects.

Morphology: Neighbourhoods built on old haciendas. Irregular blocks, scattered, organic settlement.
Referred to: http://www.ucl.ac.uk/dpuprojects/Global Report/pdfs/Lima pdf

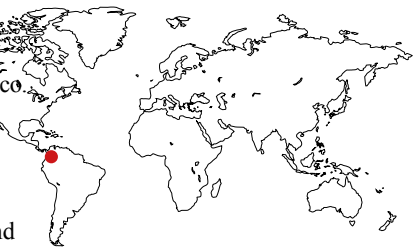

Referred to: http://www.bdigital.unal.edu co/18400/1/14210-42269-1-PB.pdf 


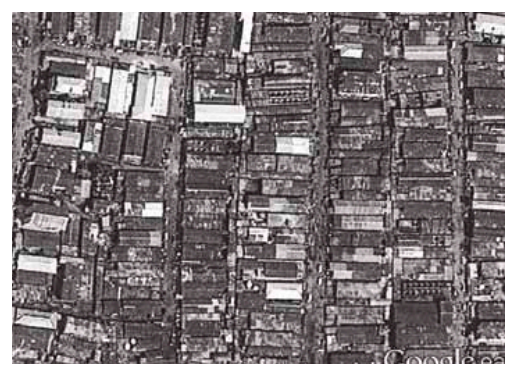

$6^{\circ} 26^{\prime} 44.86^{\prime \prime} \mathrm{N} 3^{\circ} 19^{\prime} 44.93^{\prime \prime} \mathrm{E}$ AMSL $5 \mathrm{~m}$, obs. dist. $0.6 \mathrm{~km}$
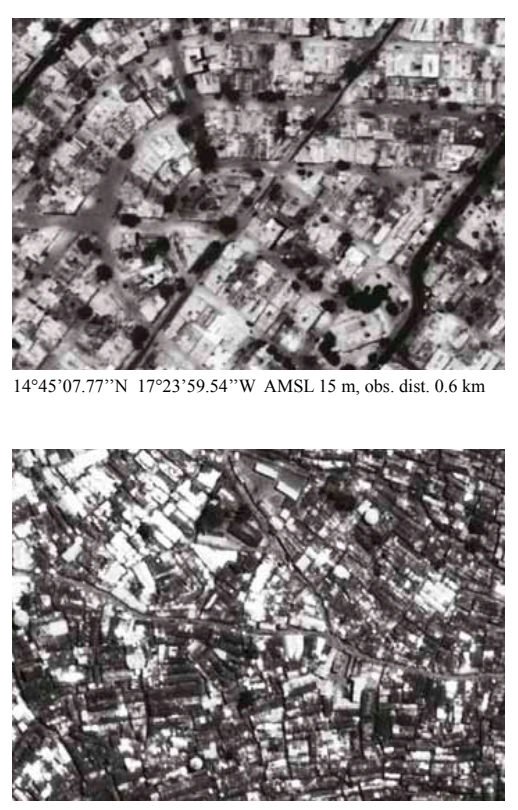

$1^{\circ} 18^{\prime} 53.34$ ”S $36^{\circ} 47^{\prime} 05.34^{\prime \prime}$ E AMSL 1723 m, obs. dist. 2.2 km

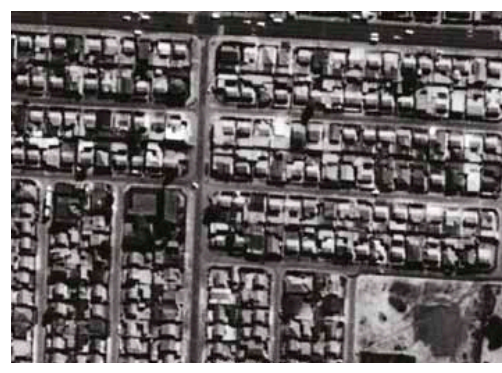

$26^{\circ} 14^{\prime} 51.23^{\prime \prime S} 27^{\circ} 50^{\prime} 58.98^{\prime \prime}$ E AMSL $1649 \mathrm{~m}$, obs. dist. $2.2 \mathrm{~km}$

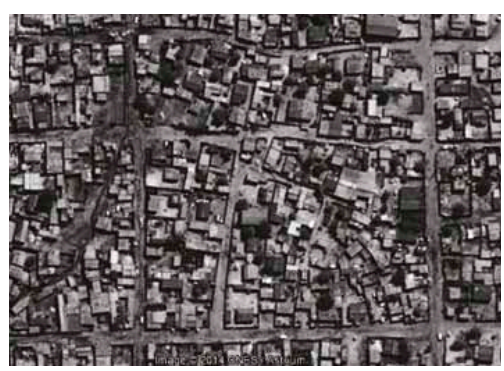

$8^{\circ} 49^{\prime} 48.14^{\prime \prime} \mathrm{S} 13^{\circ} 18^{\prime} 21.76^{\prime \prime} \mathrm{E}$ AMSL $72 \mathrm{~m}$, obs. dist. $0.7 \mathrm{~km}$

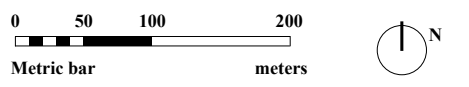

\section{AJEGUNLE}

Lagos, Nigeria

Common name: "Jungle city"

Area: 208 ha.

Population: 429,381 (2013).

Density: 750 inhab./ha (1995).

Characteristics: Multi-ethnic population deals with commerce and other informal activities (carpentry, brick laying and art work,...). Planned: Unplanned settlements.

Morphology: Structure ranging in size from clusters of shacks to entire districts. Buildings as Brazilian type (vis-á-vis) or rooming apartment. Longitudinal bands, informal structure, in some parts organisation as 'cul-de-sac'.

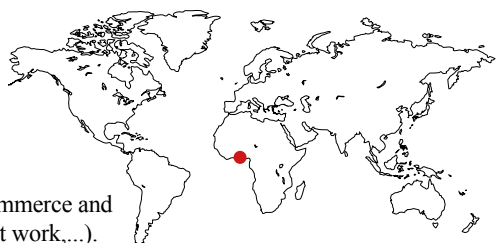
CORP2010_148.pdf www.banglajol.info/bd/index.php/ SEAJPH/.../12416
Referred to: http://www_corp.at/archive/

\section{PIKINE \\ Dakar, Senegal}

Foundation: Founded 1952, 1990 (established as city). Area: $95 \mathrm{~km}^{2}$.

Population: 1,101,859 (2013).

Density: 13,000 inhab./ $\mathrm{km}^{2}$ (2013).

Characteristics: Deliberately installed $13 \mathrm{~km}$ from Dakar by the public authorities (to reduce the congestion in la Medina). Urban mobility (Dakar towards Pikine).

Planned: Land plots have been distributed by the State, subject to the condition of developing them.

Morphology: Mixed configuration of urban cells: regular/irregular, legal/illegal, subdivided/non-subdivided. A contrast in morphology.

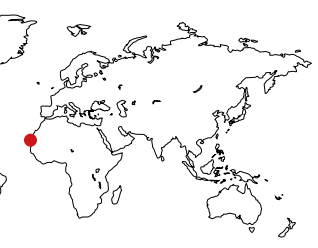

Referred to: http://archnet.org/system/publications/contents/2642/original/DPC0153. pd?? 1384766749

\section{KIBERA \\ Nairobi, Kenya}

Foundation: Founded in the early 20th century. Area: 223.4 ha (1999)

Population: Sources suggest that the total Kibera population may be 500,000 to over $1,000,000$.

Density: 2,000 inhab./ $\mathrm{km}^{2}$ (2013).

Characteristics: As a result of World War I, it became a resettlement area for Nubian soldiers returning from service.

Planned: Informal settlements were excluded from city authority planning and budgeting processes.

Morphology: Unyielding topography. Structures (houses) are

constructed largely of temporary materials. Flocking pattern.

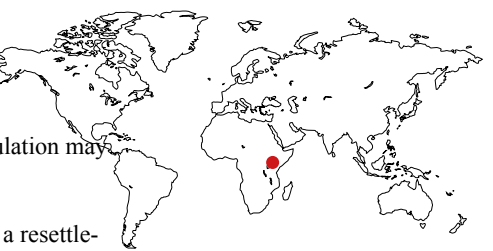

Referred to:http://tuengr:com/V02/197213.pdf

\section{SOWETO \\ South Africa}

Name: Acronym of SOuth WEst TOwnships (1963).

Foundation: Founded in 1930s as Orlando.

Area: $200.03 \mathrm{~km}^{2}$.

Population: 1.3 million (2008).

Density: 6,400 inhab. $\mathrm{km}^{2}$

Characteristics: For black people under the apartheid system.

Planned: Introducing area separated from white suburbs, so-called

"cordon sanitaire"; the infamous "Urban Areas Act" in 1923.

Morphology: Prefab-slum, regulated, complex of "matchbox"

houses, or four-room houses built by the government. Array pat-

tern that surrounds voids.

Referred to: http://wwwjoburg-archive. co.za/2003/budget/idp/annex42.pdf

\section{CAZENGA \\ Luanda, Angola}

Foundation: 17 th century.

Area: $41.6 \mathrm{~km}^{2}$.

Population: Official 668,621, survey 2,073,000 (2012).

Density: 306 inhab./ha.

Characteristics: The figurative centre of homes is a "quintal", an enclosed yard, which serves for multiple uses.

Planned: Government's strategy for decentralisation and municipal development.

Morphology: Organized “musseques". Residential area built as an extension of formal city; reticular streets and houses built with bricks/cement blocks. Landscape pattern, "leaf" organisation.

Referred to:http://cazenga.forum.angonet org/wp-content/uploads/2013/01/CazengaAtlas-English.pdf 


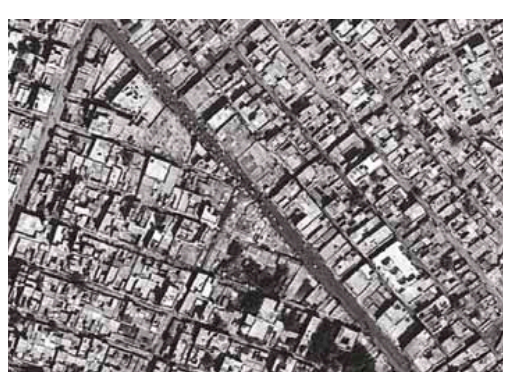

$24^{\circ} 58^{\prime} 28.32^{\prime} \mathrm{N} 66^{\circ} 59^{\prime} 06.72^{\prime}$ 'E AMSL $66 \mathrm{~m}$, obs. dist. $0.7 \mathrm{~km}$

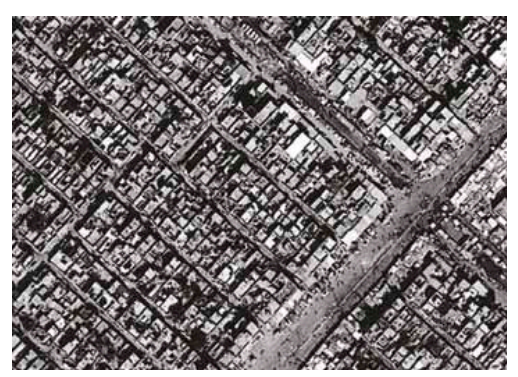

$33^{\circ} 23^{\prime} 20.50^{\prime \prime} \mathrm{N} 44^{\circ} 27^{\prime} 34.52^{\prime \prime}$ E AMSL $38 \mathrm{~m}$, obs. dist. $0.6 \mathrm{~km}$
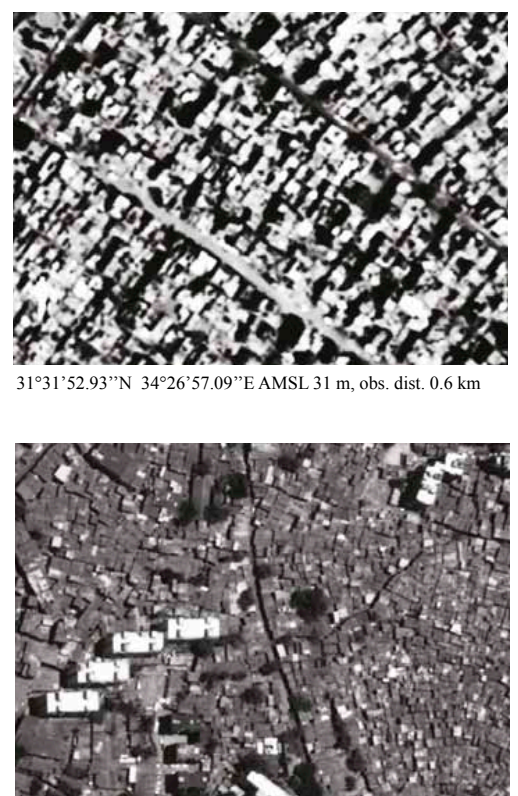

$19^{\circ} 02^{\prime} 40.30^{\prime \prime} \mathrm{N} 72^{\circ} 51^{\prime} 18.92^{\prime \prime} \mathrm{E}$ AMSL $6 \mathrm{~m}$, obs. dist. $0.6 \mathrm{~km}$

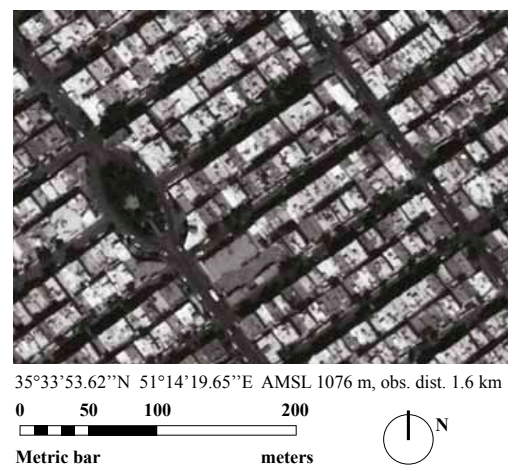

\section{ORANGI TOWN}

Karachi, Pakistan

Foundation: In 1940s, founded 14 August 2001. Area: $60 \mathrm{~km}^{2}$.

Population: Approx. 2.5 million, officially 1,540,420 (year 2010) Density: 2266.9 inhab. $/ \mathrm{km}^{2}$ (Karachi West)

Characteristics: "Katchi abadis". The population began to grow from 1965 onwards as a residential extension to the Sindh Industrial and Trading Estate (SITE).

Planned: Orangi poverty alleviation project (Orangi Pilot Project, OPP) was initiated by Akhtar Hameed Khan in 1980.

Morphology: Informal developers, planned on a gridiron pattern; rows, logitudinal narrow bands, "party" wall and two plots.

Referred to: http://www.ucl.ac.uk/dpu-projects/Global_Report/pdfs/Karachi.pdf

\section{SADR CITY \\ Baghdad, Iraq}

Name: Once known as Saddam City, also as Al Thawra

- 'Revolution City'. Today named after Imam Mohammed Sadr. Foundation: 1959 by Prime Minister Abdul Karim Qassim. Area: around $20 \mathrm{~km}^{2}$

Population: Over 2 million (largest Shi'a population)

Characteristics: "Aided self-help housing" scheme; planning policy "freedom of choice".

Planned: In 1958 Iraq Development Board assigned to DA (Doxiadis) a preparatory for regulatory plans; housing for the population in need (in accordance with the principles of Ekistics). Morphology: Neighborhoods are tightly packed. Regular grids.

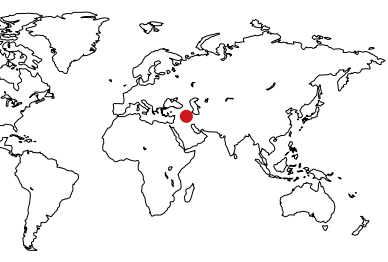

Referred to: http://www.globalsecurity.org/ military/world/iraq/sadr-city-imagery.htm http://www.academia.edu/723630/Containing_Baghdad_Constanitnos_Doxiadis_Program_for_a_Developing_Natio

\section{GAZA \\ Palestine}

Foundation: The Gaza Strip, 1948.

Area: $360 \mathrm{~km}^{2}$.

Population: 1,816,379 (2014), 1 million of them UN-registered refugees (2010). Density: 4,822 inhab. $/ \mathrm{km}^{2}$ (2012, The Gaza Strip) Characteristics: Refugees from the Arab-Israeli conflict in 1948 and their descendants. Movement restrictions.

Planned: Land laws were imposed under the Ottomans, British Mandate, Egyptian administration and under Israeli occupation, leaving Gaza with multiple layers of different planning orders. Morphology: Dense clusters along irregular corridors, grid structure; four spatial frames: ridge, main road, and edge conditions.

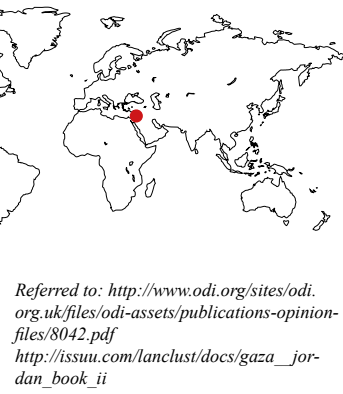

\section{$14 \mid$ DHARAVI}

Mumbai, Maharashtra, India

Foundation: In 1880s during the British colonial era. Area: over $2.3 \mathrm{~km}^{2}$

Density: 293,000 inhab. $\mathrm{km}^{2}$

Population: between 700,000 and 1 million.

Characteristics: In the 18th century, Dharavi was an island. Today: located between Mumbai's two main suburban railway lines. Planned: 1985 a master plan for Dharavi (public health hazards). From 1997 plans to redevelop Dharavi as a former slums. "Reinventing the district on the plotting table".

Morphology: Organic growth process with "capillary mutations". Curved lanes, irregular composition, the original topography, etc.

\section{5 | ESLAMSHAHR \\ Tehran, Iran}

Named: Islam-shahr known as Qasem-abad -shahi or Qasem-abad-khalese.

Foundation: In early 1970s still a rural village. Population: 357,171 (2006).

Characteristics: "Fringe settlements". Athari and Rafiee (1995) argue that "informal settlements did not exist prior to the implementation of the Tehran Master Plan in 1968".

Planned: Urban interventions in informal areas called "formalisation process of informal settlements in Iran" (2005). Morphology: Formal plot subdivisions layouts and street patterns made by the settlers, private dealers and informal developers aspect of many formal areas in the country. files/8042.pdi dan book ii

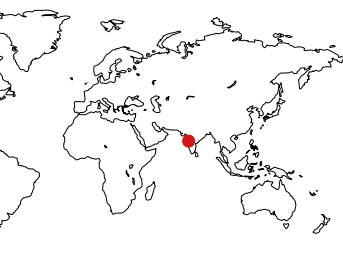

Referred to:http://www.kef-research.at/ fileadmin/media/stories/downloads/Projektberichte/P184_final_report_engl_appendix.pdf

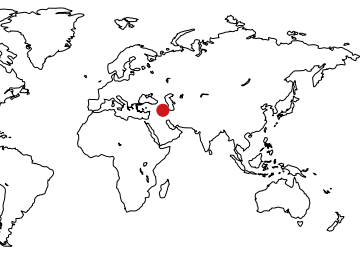

Referred to: http://www.subtropicaldesign. org.au/wp-content/uploads/2014/07/ISUF Papers Master Document Final.pdf 
- Analysis of satellite imagery system. It encompasses complex digital simulations such as: Esri, DigitalGlobe, GeoEye, Getmapping and the GIS User Community, which is combined with geodata from sources as Google Earth, Google Maps and Bing (see Table 2). It offers precision regarding dimensions, location, scales and orientation.

- Scalar exploration and size comparison through the mapping of regularity vs. irregularity of slum regions (macro scale) and local self-organisation (micro scale) by using CAD mapping and planar/ axonometric digital representation via mixed media (see Table 2).

This study reveals the unseen interconnections between urban patterns of slums with exemplary resilient geometries (e.g. Salat et al. 2014) and their 'geometrical genetics' (e.g. Menges, Ball 2012). This section of our research is not oriented towards a study of fractal analysis (which has been explored by several authors as Barros, Sobreira 2002; Torrens 2000) but we try to find taxonomic similarities regarding the functioning of informal patterns as self-ruled living organism.

\section{The process of changes and stability vs. instability}

The unstable process of changes in informal urbanism is closely related to short-time frames persistence. Samples whose structural arrangements over a lifetime are associated with a stable process of evolutionary development where stability prevails. The word 'stable' itself is very layered, complex, and has multiple meanings. Is stability also a term applicable in slums? Among the eligible parameters to track stable/ unstable slum pattern making can be done throughout the metrics of population, density and mobility. For instance, the slum of Pikine shows the best case of population instability (mobility from Dakar to Pikine; Sow 1983; see Table 2b). On the other hand, the vulnerability of natural or man-made hazards (i.e.: floods, fires or earthquakes) has a significant impact in a system of stability that can erase the fragile story of slums in just seconds. The case of the latest earthquake in Haiti shows a 'predictable disaster' (INURED 2010) with thousands dead, hundreds of thousands injured and homeless, and the city's infrastructure perished. Hence the meaning of time is crucial because it affects the definition of the urban process (case of Soweto, Fig. 1), which only represents a sporadic momentum of stability or a latent tragedy. In this sense, the notions of uncertainty and transformation lie in the essence of any slum making and its continuity.

\section{Dynamic flows in nucleation vs. dispersion}

Informal settlement systems are very diverse. They are in constant variability at a systemic level as well as in relationship to its immediate adjacent areas. Variability derives from unstable urban patterns, which are discontinuously in motion. In this sense, we are talking about the process of nucleation vs. dispersion, and vice versa, at the level of socio-spatial transformations. What is the suitable spacing between cell-structures? For instance, the domestic density of Cazenga is 9.3 people/household (Forum Cazenga 2012; see Table 2c); Ajegunale 7-9 people/household (Olajide 2010; see Table 2b); and of Pikine more than five people living in a room (e.g. Akinwale et al. 2013; see Table 2b). Concentrated or compact settlements may affect in reducing the distances between neighbourhoods and offer culturally a variable sense of social proximity.

\section{Self-organisation as a model of land occupancy}

In her study of non-planned settlements, Schaur (1991) affirms that the self-generating forms (the definition in which the form is understood not just as a shape but as an expression of the form-generating factors causing the form) evolve from physical forces in autonomous processes and as a result of a new equilibrium. Nonetheless what does it have in common with the self-organisation of urban patterns? The answer lies in the logic of 'short cuts'. Each one occupies or takes the shorter distance between two or more points. If we think about the term 'self-organisation' it is immediately connected with a spatial disorder, a process of informalisation. Now let us link it with the notion of slums as cities and within cities. We immediately pop up a repertoire of elementary frames, low-tech fabrication, aggregative groupings, and simple proportions, with up to two-story dwellings. It dominates a single domestic unit differentiated in cell-structures or "all-in-one-room" unit. This archi-type of spatial organisation is commonly repeated in all slum areas. It manifests itself at macro or micro scales. Regarding the sense of prevalence (or predominant self-array), there is macro-pattern represented as a slum fabric and also micro-pattern defined as "slum-cells".

By comparing them as areas at similar scale, we can see these phenomena as a totally different image. The case of Sadr city, an occupied area of $20 \mathrm{~km}^{2}$ (this master plan for Baghdad was based on a planning principle of linear expansion, a model that C. A. Doxiadis coined as 'Dynapolis'; Theodosis 2008; see Table 2c), reveals a 


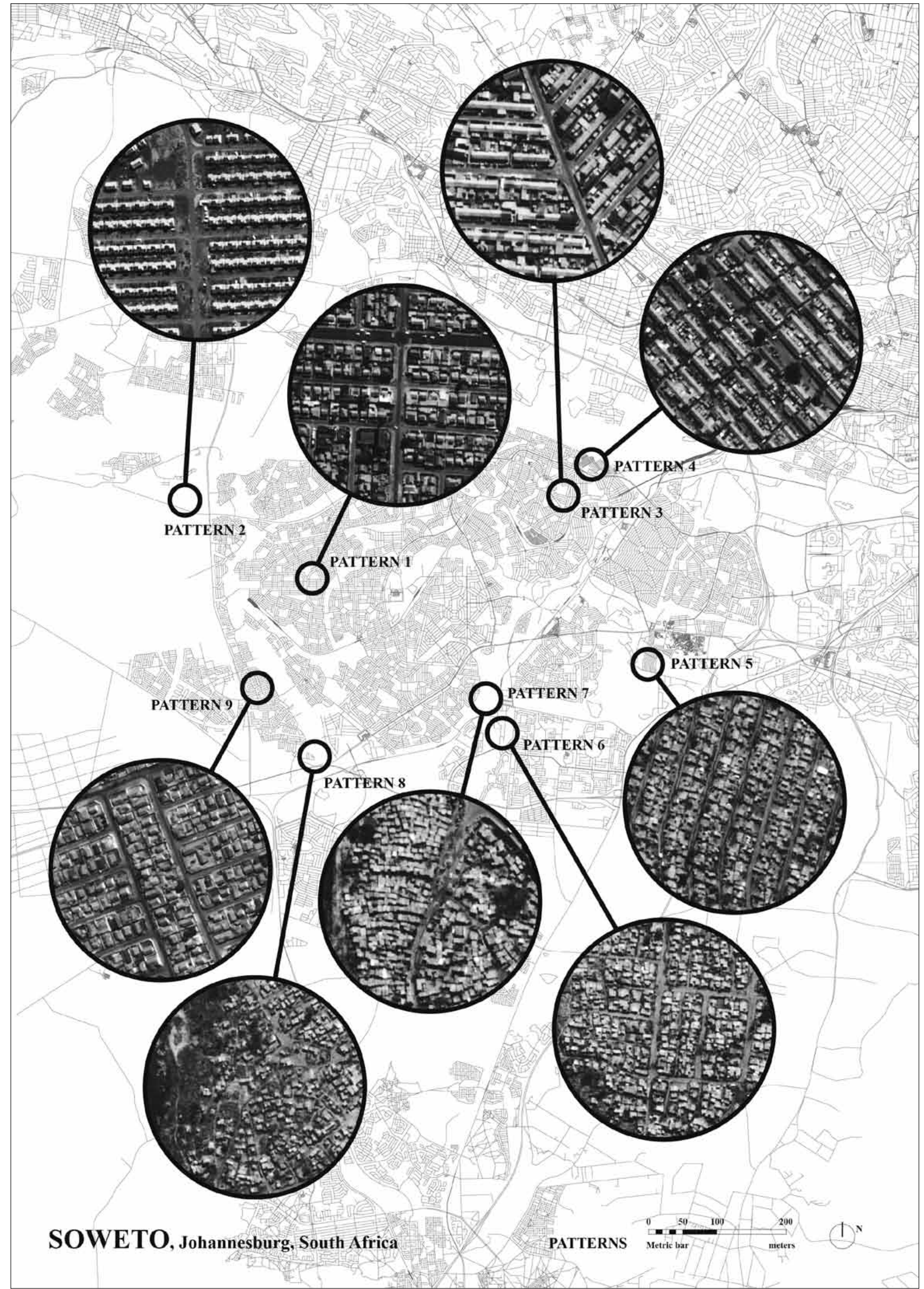

Fig. 1. Soweto - table of slum patterns: from irregular informality to regular formal organisation 
regular grid at macro-scale and a randomised array at micro-scale. In the case of Kibera (see Table 2b) with $2.3 \mathrm{~km}^{2}$ of area -it prevails a self-organisation and high-dense fabric as a slum-in-slum scheme. On contrary, the case of Libertador (see Table 2a) -an occupied area of $34 \mathrm{~km}^{2}$-is telling another trend. The main feature is a self-occupancy within a self-organised organism, which has instinctively built dynamics of micro and macro urban compositions.

\section{A question of boundaries?}

To continue with a question of scale and bigness between Slum city and City with slums we are faced with a question: Where does the slum start? Is the beginning of a slum the end of a city? What are the border types between the city and slum patterns? Can we detach them from other structures? Are there any limits that define regular/irregular slum structures or is it merely a matter of survival occupation of urban gaps? Regarding boundaries we can observe that the slum has its physical borders or demarcations if the slum is limited by the presence of other formalised city structures (the case of Dharavi; see Table $2 c$ ) or it is not a peripheral zone (Kibera; see Table 2b); and it is limited by natural obstacles (Libertador; see Table 2a) or by political frontiers (the case of Gaza; Table 2c).

\section{The slum as a complex urban system in motion}

"A pattern is essentially a structure which connects other structures or rather a metastructure" (Bateson 1979).

The comparison of urban structures between slums - which belongs to different geographical and cultural backgrounds - reveals the presence of recurrent traits. The same is applicable to human life; the rhythm of which follows precise temporal and spatial patterns, i.e.: cycles marked by certain necessities, recognisable and orderable which structure our existence. Situations that occur in mankind are also recurring in his customs and urban routine. It is evident, that human life does not only revolve around common demands, but throughout complex means that satisfy both existing and surprising similarities (Zappulla 2014).

In fact, in spite of their different geographic, cultural and socio-economic contexts remarkable similarities/ differences might be interlaced by studying the urban structure of informal cities. The latter is linked with the organisation of their territories and specific settlement patterns, which result from complex relationships between urbanities, public sector and communities living in conditions of informalised cultural and economic autonomies. These are patterns of marginalised urban habitats that face exclusion and being forced to parasitise city-by-city along a life cycle. These relationships of dependencies become the background where the spontaneous city takes form by weaving a controversial dialogue between informalised and regimented ones. We can define slum as a complex sub-system within a major urban system (Barros, Sobreira 2002), in which all key factors are interconnected or rather are the result of the interaction between various factors where patterns appear as the medium capable to group and signify them. And these "urbanities without urban planners" express this concept of complex systems with the presence of life, in which we interplay with multiple interconnected variables, where social aspects interact with the built environment, its architecture, urbanism and landscape. Like in every complex systems, slums release behaviours that cannot be predicted by the analysis of individual or separate elements but only from their interrelationships.

Within mega-slum systems, these relationships are interweaved and discontinuous. Pattern Recognition (PR) can be a method for understanding both morphological common features and organisational dynamics. Patterns are structures that our minds easily signify, identify, organise and connect in terms of scale, geometrical templates and abstract forms at macro and micro levels. In doing so, they are the amalgamation established between dwellers, dwellings and the communication networks within the built environment.

\section{The taxonomic tree of global slums}

Prior to understanding how the relationships of pattern framing work, it is imperative to consider their formal description and graphical pattern pathways. In doing this, 31 worldwide slums have been selected, analysed and compared from the north and south hemispheres, mainly in the Americas, Africa and Asia:

\section{Latin America}

(1) Ciudad Nezahualcóyotl, State of Mexico, Mexico;

(2) Tlalpan, Mexico City, Mexico; (3) Libertador, Caracas, Venezuela; (4) Sucre, Caracas, Venezuela; (5) El Recuerdo Sur, Ciudad Bolívar, Bogotá; (6) San Juan de Lurigancho, Lima, Peru; (7) Cono Sur, Lima, Peru; (8) Pampahasi, El Alto, Bolivia; (9) AguasBlancas, Valledupar, Colombia; (10) Villa 31, Buenos Aires, Argentina; and (11) Cité Soleil, Port-auPrince, Republic of Haiti.

\section{Africa}

(12) Masina, Kinshasa, Democratic Republic of the Congo; (13) Ajegunle, Lagos, Nigeria; (14) Soweto, Johannesburg, Gauteng, South Africa; (15) 
Cape Flats, Cape Town, South Africa; (16) Inanda, Kwa Zulu-Natal, South Africa; (17) Pikine, Dakar, Senegal; (18) Imbala, Cairo, Egypt; (19) Ezbet, El-Haggana, Cairo, Egypt; (20) City of the Dead, Cairo, Egypt; (21) ManshiyatNaser, Cairo, Egypt; (22) Cazenga, Luanda, Angola; (23) Kibera, Nairobi, Kenya; (24) Mathare, Nairobi, Kenya; and (25) Agege, Lagos, Nigeria.

Asia

(26) Sadr City, Baghdad, Republic of Iraq; (27) Gaza, Palestine; (28) Orangi Town, Karachi, Pakistan; (29) Dharavi, Mumbai, India; (30) Tehran, Eslamshahr, Iran; and (31) Altındağ, Ankara, Turkey.

After a refined selection of the most representative cases, only 20 test cases were chosen: Nezahualcóyotl, Libertador, San Juan, Villa 31, Cite Soleil, Masina, Ajegunle, Soweto, Cape Flats, Pikine, Imbala, Ezbet, City of the Dead, Manshiyat, Cazenga, Kibera, Sadr city, Gaza, Orangi, and Dharavi. They have been systematised through a schematic taxonomic tree (Fig. 2). This classification allows to establish unexpected similarities and differences within the same family pattern and to consider each slum structure as the combination of several factors. For example, the macro tissue of Nezahualcóyotl has a regular form which follows a rectangular macro-grid pattern with courtyards at macro level. Moreover, if we analyse the micro cell that defines the tissue we realize that it is the result of infill units, which follows certain iterations.

\section{Are slum systems natural-like patterns?}

Does irregular urban growth mean that cities will shift into chaos, sprawl slums or loss of public control? Can slum growth find out genuine and optimal spatial frameworks? Meanwhile we attempt to enforce regularity against dysfunctionalities in terms of land-transport networks, living spaces and so on (Ball 2009). Despite of mono-functional planning regulations that impose simplistic orders and that there is a global trend towards informalism, then slums, shanty cities or squatter areas appear as the best cases for non-geometrical and unplanned urban grids. When the slums are not formally configured, organic patterns emerge out of instability such as the visible cracking on the bed of dried ponds or the leaf branching.

Compared to the regular grid in formal cities, slum patterns are more resilient due to their obedience to self-organising and site-specific conditions (topographic and topological variables). In fact, they are not the result of any top-down strategy, but as in biological structures or vernacular settlements, they emerge from bottom-up interfaces. They are the inevitable result of urban dynamics in constant transformation. Moreover, the instantness of the slum making is a spontaneous building process, which always finds its raison d'être regarding maximum spatial efficiency and minimum energy use.

If formalised urban patterns are predominantly considered generic planar manifestations, slums offers an adjustable urban framework - a continuous crustformed by a constant thickness up to two or three-story buildings. In general, this informalised layer is topographically mimetic even do transgressive and out-ofcontrol. It mainly follows organic dialogues characterised by the complexity of "fractal-like patterns not very different from those displayed by natural systems" (Buhl et al. 2006).

In addition, the study of path systems made by Otto and Burkhardt (2009) deals with impressive similarities between both non-living and living natural formations in (dragonfly's wing, maple leaf, crack pattern, stoneware glaze) and human settlement patterns (such as Istanbul road network or villages in Serengeti), which are accidental pictorial analogies. For instance, the urban structure of streets is metaphorically camouflaged with the foliage structure of a deciduous tree (e.g. Otto, Burkhardt 2009). This study shows that branching or ramification is the most common surface pattern used by nature to establish connections. This template is also present in the water paths from the mountain to the sea, in the majority of fluid, energy or transport systems, from the plants to the nervous or blood system. Slums follow the logic of animal architecture (Von Frisch 1974).We can find branching structures in animal settlements such as ants, termites, wasps, and bees. Even the primordial human connective paths are branching based.

Why are almost all these selected cases sharing a common trend in pattern making? There are reasons to believe that the branching system is the most efficient eco-systems for transferring biological and technical nutrients and energy flows from concentrated nodes to wider areas and vice versa. In slums waste is food ${ }^{8}$. Moreover, the branching is not only a connective system but also a geometrical support for maximising the occupation and production of space. For this reason the slum-frame is a structure globally spreads a mong various urban manifestations (Batty 1994).

\footnotetext{
8 More details in Braungart, M.; McDonough, W. 2002. Cradle to cradle, remaking the way we make things. New York: North Point Press; and in film "District 9", 2009 directed by Peter Jackson, info about: http://www.imdb.com/title/tt1136608/ [accessed in 15 September 2014].
} 


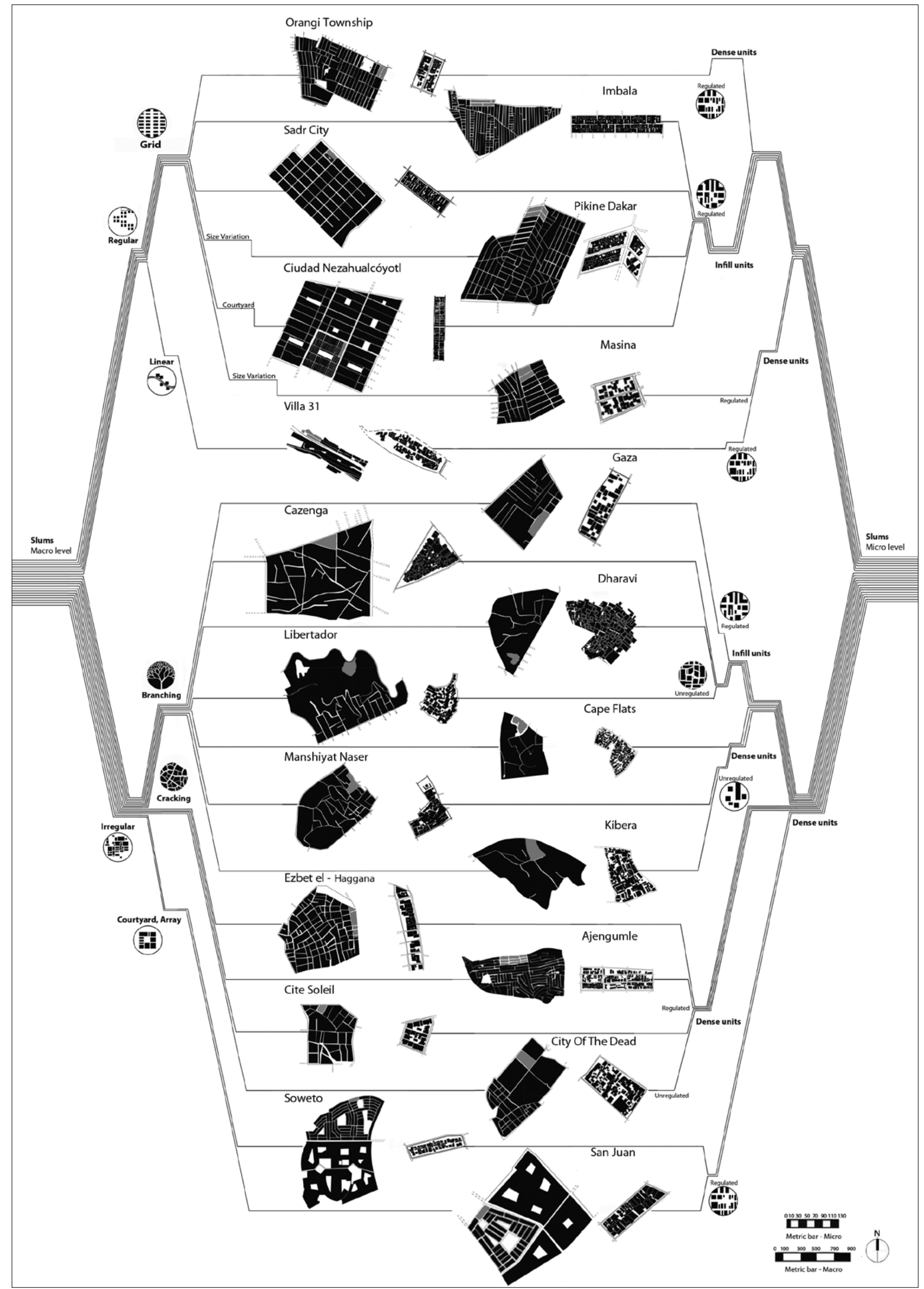

Fig. 2. The taxonomic scheme of slums. Source: authors and Sameera Chukkapalli (2014). 


\section{Patterns of slums: macro vs. micro}

From the analysis of the studied cases, a profound difference appears between the tissue-pattern perceived from a far viewpoint of settlements (at macro scale) and the cell-pattern revealed at micro scale. On a macro scale, the most diverse urban organisations are manifested through regular grids, courtyard array, linear type, branching, and cracking. These are resulting from specific urban conditions, non-regulations, physical and cultural contexts, and economic and social forces. The regular grid is mainly the product of a an initial game plan where the infrastructural boundaries per sector are pre-defined; the voids or public courtyards appear as catalysts of public life; the linear block-type is an aggregation of housing units that follow an attractor like road, contours or river. If the previous organising patterns derive from a strong relation with a pre-existing element, the branching and the cracking emerge as an agile antidote for slum making.
The relationship between the informal settlement and its geomorphological context profoundly influences the organisation and production of slum pattern at macro levels, whilst this relationship is only confined to dialogues between the built form and the immediate boundaries at micro levels. The findings offer a threefold result (see Table 3, Table 4): (a) differences between macro and micro patterns; (b) micro pattern is more independent from the context; (b) less variety among patterns at micro scale worldwide.

Even if we consider any slum as a system characterised by a macro grid pattern - followed by a closer focus on the dwelling distribution -, new patterns (orders) emerge that do not consider the major array. These micro-patterns are based on specific decisions and choices taken by occupants, according to the common sense of contingent constraints such as: sharing-wall principle, minimal inner circulation, and availability and supply of building materials. Therefore these principles depend on land-use efficiency, energy sources and the optimisation of available resources.

Table 3. Patterns of slums: macro scale

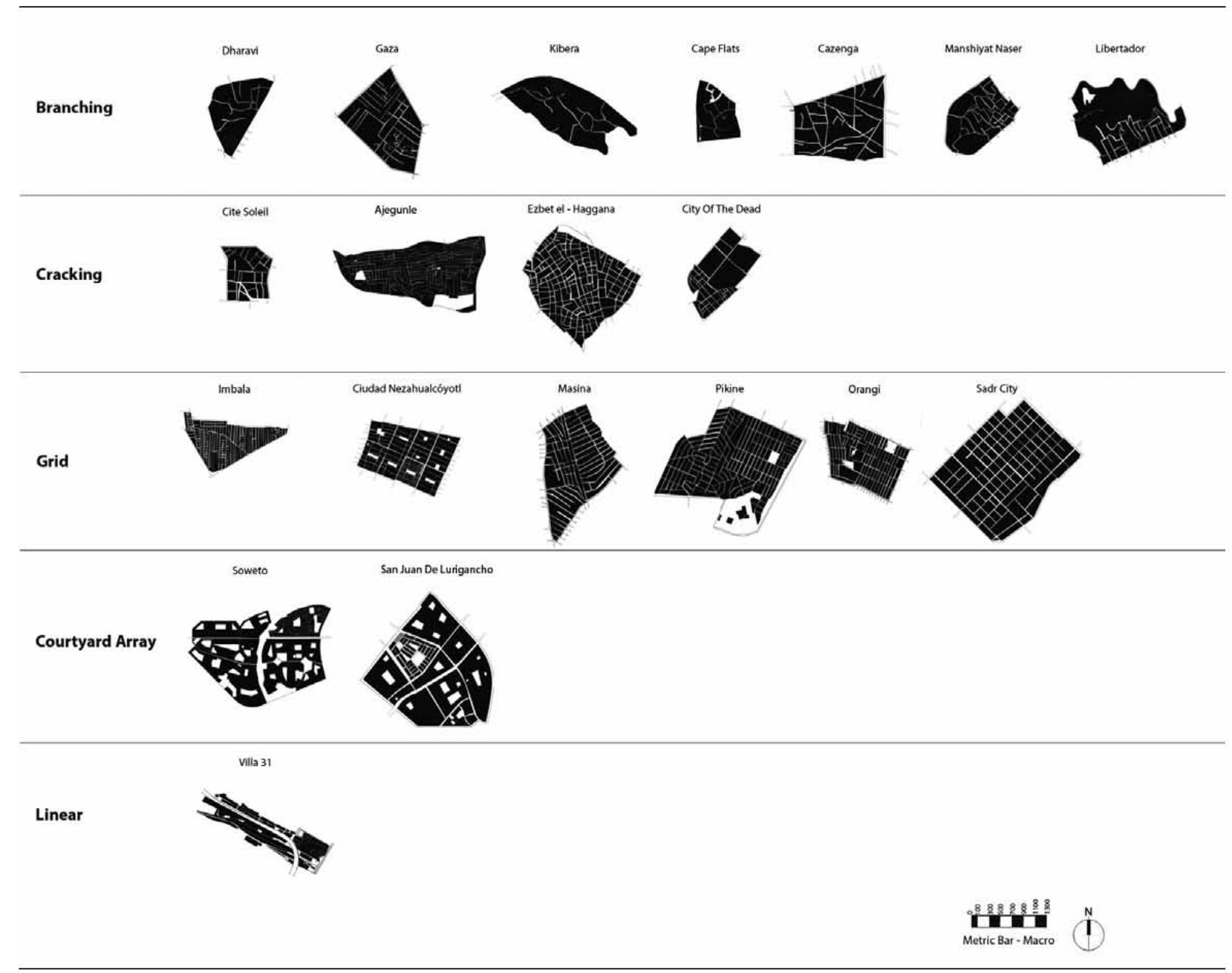

Source: authors and Sameera Chukkapalli (2014). 


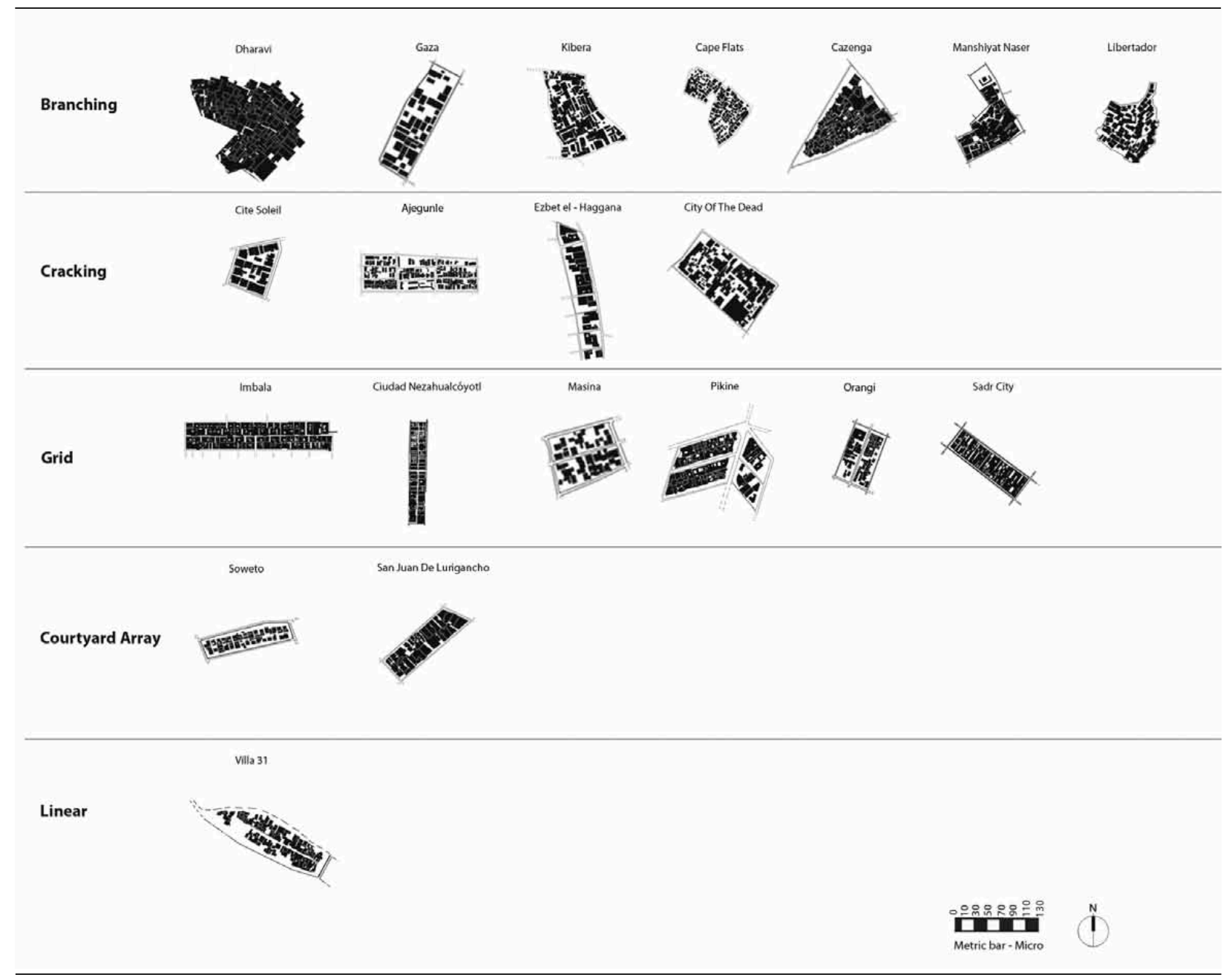

Source: authors and Sameera Chukkapalli (2014).

At small scale it is possible to recognise a sort of common pattern behaviour that is transcultural and trans-topographical as well. It consists of an infill process where the cells multiply according to a process of total land occupancy and reclamation. Dharavi is an emblematic slum case to represent this process. Here the dwellings rest on each other by covering almost the entire internal circulation system and generating a continuous and homogeneous fabric. Nonetheless, is the macro pattern affecting the micro one, or vice versa? Who informs whom? Is micro both structured and structuring? In reality, the situation is not extensive. Although there are good reasons to think that the 'bottom-up' local conditions could inform complex patterns on a large scale, in reality most of the chosen cases are defined as regular geometries that anticipate and drive the self-organisation of each settlement. Instead of having continuous planning rules, an autonomous, intermittent and transformative pattern emerges at all scales.

\section{Conclusions}

How can the self-organisation of slums inform urban planning? Top-down projects are based on the planning capacity of envisioning the future or forecasting scenarios in which the community will live in diverse and autonomous urban spaces. By following any resilient urban structure, we should encourage a bottom-up model based on cellular spatial aggregations at micro scale that construct an evolutionary tissue at larger scales. The lesson of slum evokes a 'collage city making' where the micro-urbanism enhances the macro-urbanism and vice versa throughout a feedback loop process controlled by dwellers.

In this sense, slum pattern making represents not only the production of urban or housing poverty but also the richness of a complex, motional and organic urban process where the theory of complexity can help conventional planning to rethink an unlevelled repertoire of new social and spatial configurations. 
We are accustomed to think of slums as settlements without any form of organisation, the telling story of a sin-city, which must be isolated, confined or eradicated. As far as we consider slums as separate systems from the formal city, we will never be able to tackle the complexity of the contemporary urban morphologies, mutations and pattern pathways.

The study of slums patterns can re-evaluate the importance of randomised urban structures in nowadays cities. When complex geometries arose, the power of scalability articulates the missing link between territorial, urban and local levels. In fact, branching pattern can interpret multiple connections within its formal structure, which is gradually transformed into slower communications by embedding the human scale and claiming primal meanings between occupants and habitats.

Research on the connectivity of urban forms indicates that the most functional towns are those with a multiple number of interconnections at all scales, from the pedestrian to bicycle paths, from low traffic transport road and to highways, according to a fractallike tree diagram. Salingaros claims the importance of randomised geometry as a conceptual and operational tool that evaluates the architecture and urban planning at the human scale and allow to embrace the indispensable gradient to the establishment of a biofilic city (e.g. Salingaros, West 1999).

Can cities dignify contemporary urban structures like squatter settlements or slums? According to the Global report on Human Settlements (United Nations Human Settlements Programme, UN-Habitat 2003), "almost 1 billion people, or 32 per cent of the world's urban population, live in slums" (Annan 2003).It is mandatory to consider all slums as part of the city with its social and spatial potentialities to consolidate flexible urban tissues within its life cycle. It is not simple, but through the proactive involvement of inclusive city-makers and effective civic strategies on the-rightto-the-city can generate awareness and enhancement for a better urbanity. Digitalism and satellite imagery are didactic supports to decipher the meaning and morphology of new complex urban systems such as informal and randomised pattern drifts.

\section{References}

Akinwale, O. P.; Adeneye, A. K; Musa, A. Z.; Oyedeji, K. S.; Sulyman, M. A.; Oyefara, J. O.; Adejoh, P. E.; Adeneye, A. A. 2013. Living conditions and public health status in three urban slums of Lagos, Nigeria, South East Asia Journal of Public Health 3(1): 36-41. http://dx.doi.org/10.3329/seajph.v3i1.17709

Annan, K. A. 2003. Foreword, in United Nations Human Settlements Programme (UN-Habitat). The challenge of slums: global report on human settlements. Sterling, VA: Earthscan Publications Ltd.

Ball, P. 2009. Branches: nature's patterns: a tapestry in three parts. Oxford: Oxford University Press.

Barros, J.; Sobreira, F. 2002. City of slums: self-organisation across scales [online], [cited 10 September 2014], in International Conference on Complex Systems (ICCS2002), 9-14 June 2002, Nashua, NH, USA. London: Centre for Advanced Spatial Analysis, University College London. Available from Internet: https://www.bartlett.ucl.ac.uk/ casa/pdf/paper55.pdf

Bateson, G. 1979. Mind and nature: a necessary unity. NewYork: Bantam.

Batty, M.; Longley, P. 1994. Fractal cities: a geometry of form and function. London, San Diego, CA: Academic Press Limited.

Braungart, M.; McDonough, W. 2002. Cradle to cradle, remaking the way we make things. New York: North Point Press.

Brenner, N.; Peck, J.; Theodore, N. 2012. Afterlives of neoliberalism. London: Bedford Press/Architectural Association.

Buhl, J.; Gautrais, J.; Reeves, N.; Solé, R. V.; Valverde, S.; Kuntz P.; Theraulaz, G. 2006. Topological patterns in street networks of self-organized urban settlement, The European Physical Journal B 49: 513-522.

http://dx.doi.org/10.1140/epjb/e2006-00085-1

Davis, M. 2006. Planet of slums. London: Verso.

Forum Cazenga. 2012. Cazenga Atlas [online], [cited 15 September 2014]. Available from Internet: http://cazenga. forum.angonet.org/en/

Gilbert, A. 2011. Epilogue, City: Analysis of Urban Trends, Culture, Theory, Policy, Action 15(6): 722-726. http://dx.doi.org/10.1080/13604813.2011.609019

Gilbert, A. 2007. The return of the slum: does language matter?, International Journal of Urban and Regional Research 31(4): 697-713. http://dx.doi.org/10.1111/j.1468-2427.2007.00754.x

Jones, A. G. 2011. Slumming about, City: Analysis of Urban Trends, Culture, Theory, Policy, Action 15(6): 696-708. http://dx.doi.org/10.1080/13604813.2011.609017

Kolawole Opeyemi, M.; Michael Olabode, O.; Bili Olalekan, K.; Olufunmilola Omolola, A. 2012. Urban slums as spatial manifestations of urbanization in sub-Saharan Africa: a case study of Ajegunleslum settlement, Lagos, Nigeria, Developing Country Studies 2(11): 1-11 [online], [cited 18 September 2014]. Available from Internet: http://www.iiste.org/Journals/ index.php/DCS/article/view/3554

Korzybski, A. 1994. Science and sanity: an introduction to non-Aristotelian systems and general semantics. 5th ed. New York, NY: Institute of General Semantics.

Lefebvre, H. 1974. The production of space, contradictory space. Malden: Blackwell Publishing.

Menges, A.; Ball, P. 2012. Pattern formation in nature: physical constraints and self-organising characteristics, Architectural Design 82(2): 22-27. http://dx.doi.org/10.1002/ad.1375

Olajide, O. Urban poverty and environmental conditions in informal settlements of Ajegunle, Lagos Nigeria [online], [cited 15 September 2014], in Schrenk, M.; Vasily, V.; Popovich, V. V.; Zeile, P. (Eds.). REAL CORP 2010: Proceedings/Tagungsband, 18-20 May 2010, Vienna, Austria. Available from Internet: http://www.corp.at

Otto, F.; Burkhardt, B. 2009. Occupying and connecting: thoughts on territories and spheres of influence with particular reference to human settlement. Stuttgart: Edition Axel Menges. 
Owen, P. 2012. Inside the Kowloon Walled City where 50,000 residents eked out a grimy living in the most densely populated place on earth [online], [cited 20 September 2014]. Available from Internet: http://www.dailymail.co.uk/news/article2139914/A-rare-insight-Kowloon-Walled-City.html

Prescott, M. F.; Vollmer, D.; Heisel, F. 2013. Learning from informal urbanism [online], [cited 10 September 2014]. FCL Future Cities Laboratory Singapore ETH Centre for Global Environmental Sustainability (SEC). Available from Internet: http://www.futurecities.ethz.ch/assets/Gazette-20-Learningfrom-Informal-Urbanism.pdf

Raith, K. 2013. Development concept and guideline for the upgrading of Dharavi, Mumbai. Appendix to the final report. "Dharavi- Ground Up": a dwellers-focused design tool for upgrading living space in Dharavi, Mumbai [online], [cited 18 September 2014]. Available from Internet: http:// www.kef-research.at/fileadmin/media/stories/downloads/ Projektberichte/P184_final_report_engl_appendix.pdf

Salat, S.; Bourdic, L.; Labbe, F. 2014. Breaking Symmetries and Emerging Scaling Urban Structures. A Morphological Tale of 3 Cities: Paris, New York and Barcelona, Archnet-IJAR 8(2): 77-93 [online], [cited 15 September 2014]. Available from Internet: http://archnet-ijar.net/index.php/IJAR/article/view/445

Salingaros, N. A.; West, B. J. 1999. A universal rule for the distribution of sizes, Environmental and Planning B, Planning and design 26(6): 909-923. http://dx.doi.org/10.1068/b260909

Schaur, E. 1991. Non-planned settlements. Characteristic features - path systems, surface subdivision. Stuttgart: Institut für Leichte Flächentragwerke.

Sharma, A. 2003. Slums of the world: the face of urban poverty in the new millennium? [online], [cited 25 September 2014]. Nairobi, Kenya: United Nations Human Settlements Programme (UN HABITAT). Available from Internet: http:// archive.org/stream/SlumsOfTheWorldTheFaceOfUrban Poverty InTheNewMillennium/

Sow, F. 1983. Pikine, Senegal: a reading of a contemporary African city, in Taylor, B. B. (Ed.). Reading the contemporary African city. Singapore: Concept Media/Aga Khan Award for Architecture 45-60 [online], [cited18 September 2014]. Available from Internet: http://archnet.org/publications/2642

The Interuniversity Institute for Research and Development (INURED). 2010. Voices from the shanties. A post-earthquake rapid assessment of Cité Soleil, Port-au-Prince [online], [cited 15 September 2014]. Available from Internet: http:// www.ijdh.org/2010/03/topics/housing/inured-voices-fromthe-shanties-a-post-earthquake-rapid-assessment-of-citesoleil-port-au-prince/

Theodosis, L. 2008. 'Containing' Baghdad: Constanitnos Doxiadis' program for a developing nation [online], [cited 15 September 2014], in Azara, P. City of Mirages: Baghdad, from Wright to Venturi. Revista de crítica $y$ teoría de la arquitectura, 167-172. Barcelona: Universitat Politècnica de Catalunya, Departament de Composicio Arquitectònica [cited 18 September 2014]: http://www.academia.edu/723630/_Containing_Baghdad_Constanitnos_ Doxiadis_Program_for_a_Developing_Nation

Torrens, P. M. 2000. How cellular models of urban systems work (1. Theory) [cited 18 September 2014]. CASA Working Paper 28. The Bartlett Centre for Advanced Spatial Analysis, University College London. Available from Internet: http:// www.bartlett.ucl.ac.uk/casa/publications/working-paper-28

United Nations Human Settlements Programme (UN-Habitat). 2003. The challenge of slums: global report on human settlements. Sterling, VA: Earthscan Publications Ltd.
United Nations Population Division. 2002. World urbanization prospects: the 2001 revision: the 2001 revision data tables and highlights [online], [cited25 September 2014]. Available from Internet: http://www.un.org/esa/population/publications/ wup2001/wup2001dh.pdf

Von Frisch, K; 1974. Animal architecture. New York: Harcourt Brace Jovanovich.

Webster's Universal College Dictionary. 1997. New York: Gramercy Books.

Zappulla, C. 2014. Architecture as science of pattern?: Doctoral Thesis. Barcelona: Universitat Politècnica de Catalunya, Departament de Projectes Arquitectònics.

\section{CARMELO ZAPPULLA}

Department of Architecture (GIRAS, Research Group), Barcelona Architecture School, Polytechnic University of Catalonia, Av. Diagonal, 649-651, 08028 Barcelona, Spain.

E-mail: carmelo@externalreference.com.

Carmelo Zappulla is a $\mathrm{PhD}$ architect and founding partner of Barcelona based External Reference Architects. He argues that the use of patterns can connect architectural theory with practice, by representing, at the same time, the most relevant strains of research in contemporary design. He studied architecture at the Università degli Studi di Palermo, graduating with Honors and special mention, and holds a PhD (European Mention) with Honors from Universidad Politécnica de Catalunya, Barcelona. After working in Rotterdam and in London, he moved to Barcelona where he started collaborating with RCRA rquitectes and Foreign Office Architects. Together with Nacho Toribio, Zappulla runs, External Reference Architects, a firm active in design and research in the fields of sensorial spaces, interior design, architecture, and landscape design. He is currently faculty member at IAAC (Institute for Advanced Architecture of Catalonia) and teacher at IED (Istituto Europeo di Design), where he is also the coordinator of the Master's Degree program in Interior Design. He is member of GIRAS - Research Group on Architecture: Project, Territory and Society at Polytechnic University of Catalonia. He collaborates with different architectural schools and institutions, including WSA (The Welsh School of Architecture), the Department of Architecture at Cardiff University, Wales, Uk. His work has been exhibited at the Biennale in Venice, during the 12th International Architecture Exhibition, at MAXXI, Rome, at Eme3, Barcelona, Europan 8, Oslo. His publications include articles and projects published in Future, Il Sole 24 ore, Blueprint, Materia, Frame, Dezeen, Domus, in the books Architect's notebook and Architectural process 2014 by Damdi Publishing co, among others.

\section{CRISTIAN SUAU}

Department of Architecture, Faculty of Engineering, University of Strathclyde, 75 Montrose street, G11XJ, Glasgow, UK.

E-mail:cristian.suau@strath.ac.uk.

Dr Cristian SUAU is a Chilean-born Spanish architect. He holds a Ph.D. in Architecture and Master in Urban Design from Barcelona School of Architecture (ETSAB). He taught Architectural Design at the Welsh School of Architecture (2007-2013). Currently he is senior lecturer at the University of Strathclyde, Department of Architecture, Glasgow (UK) and the Glasgow Project Office director. In addition, he has tutored in the various European universities such as Universidad de Chile, Pontificia Catolica Universidad de Chile, Barcelona School of Architecture (ETSAB), Architectural 
Association (AA), Chalmers University (Sweden), University of Stuttgart (Germany); University of Ljubljana (Slovenia); University of Zagreb (Croatia); CTU Prague (Czech Republic) and Tianjin University (China). His research covers the fields of radical architecture, ecological urbanism, urban renewal, eco-design and non-conventional water technologies. His outputs have been disseminated in various international media and scientific events, design workshops and conferences. He is member in scientific networks such as DOCOMOMO, EAHN, ECLAS, AHRA and PLEA. Professionally Dr Suau was senior architect and project leader in the Office for Metropolitan Architecture in Rotterdam designing various projects such as Almere Homerus, Koningen Julianaplein, Prada Foundation and Prada Transfomer. He has obtained several international housing and urban design awards such as EUROPAN Norway (2006) and the international urban design award in Chile called 'Bicentenario Chile: Rambla for Citizenship' (2012). He is the principal of ECOFABRICA, a collaborative eco-design hub established in the UK and Chile: www.ecofab.org.

\section{ALENKA FIKFAK}

Chair of Urbanism, Faculty of Architecture, University of Ljubljana, Zoisova 12, 1000 Ljubljana, Slovenia. E-mail:alenka.fikfak@fa.uni-lj.si.

Dr, MA in Architecture, PhD in Architecture and Urban Planning; senior lecturer. Head of Chair of urbanism UL FA, Head of management board UL FA, member of Chamber UL FA. Leading process of accreditation - urbanism study program, 2010-2012 (Bachelor and Master), re-accreditation of architecture (Unifed Master) study program, 2012-2013. Research experience: spatial and landscape planning, planning of small settlements, rurism and rural architecture, regulatory plans for the regulation of non-urban settlements, evolutionary constants of a settlement culture undergoing renovation, with particular reference to the coastal region, models for revitalisation of degraded landscape areas, analysis of trends of spatial development. EU projects/Programmes: Sustainable settlement models and typologies for transborder territories (2004); ALPTER - Terraced landscapes of the alpine arc, Interreg III B Alpine Space (2005-2006); Cultura 2000 Virtual museum of the European Transhumance (2006-2007); Competence Centre - Sustainable and Innovative Construction (2010-13); ESPON-Train (2012-2013); Restructuring of Study Programme in Architecture to Long-cycle Integrated Master in line with EU standards, Tempus, (2012-2015). She has organised more than 30 architectural and urbanistical workshops (presentations of the work and exhibitions) for different local communities in Slovenia - population of the students work on the local level. Active in organising International conferences of Spatial Planning development and Urbanism: Smart urbanism 2012, 2013, 2014; Symposium Men and space; Theory and critic's in Architecture: 60 architectural reviews in Europe, Member of different national and international scientific and art committees. Active in professional work in domain of urban planning and design. Participated in many national competitions, with first awards as "Urban design of the city center Ravne na Koroškem, 2009”. 